\title{
Press Freedom: Analyzing the portrayal of Nigerian-State on National dailies cover-page headlines
}

\author{
Almansur Ado SANI, MA. Student, Faculty of Communication, Yasar University, Turkey, \\ mudubinkibiya@yahoo.com
}

\begin{abstract}
Freedom of the press is not only a complementary to the human rights and popular democracy, also a cardinal principle that guarantees media public sphere that facilitates public discourse and vibrant flow of political communication. In many countries, freedom of press remains contentious issue as a number of journalists are inhumanly treated by dictatorial regimes in order to achieve conformity in their individual territories. This study applies content analysis on cover page news stories of two privately owned Nigerian newspapers and analyzes the extent to which the press in the country practices in a free environment. The findings suggest that, the press in Nigeria is considerably free since it repeatedly covers issues that are considered critical to the government by giving such stories prominence to appear on the cover page. The study covers the period of two consecutive months; the selection of the newspapers is based on wide readership and geographical representation.
\end{abstract}

Keywords: Press freedom, newspapers, political discourse, content analysis, Nigeria.

\section{Introduction}

Freedom of the press is a cornerstone to judge maturity of democracy in many societies. Respect for freedom of expression and the right of public to excess and receive information result to transparency and accountability of governments. Bruns (2008) maintains that, critical independence, democratic constructiveness and commercial viability are the cardinal principles of press organization. Governments have been using license and censorship to control the power of mass media and curtail its immense contribution and defense of fundamental human rights. As a fourth realm of estate, press holds executive, legislature and judiciary accountable to the public by exercising functions of watchdog and surveillance. Ideally, media has three essential roles to play in democratization process and good governance: as a watchdog over the powerful, civic forum (for political debate) and agenda-setter (Norris 2006). In this light, of these three basic functions of media, the first has been the most difficult to exercise in third world such as Africa, due to political manipulation, conglomerates and repression of journalists (Akinwale 2010). To what extent does Nigerian press practice free press to contribute towards the development of democracy in the country?

This study addresses the above question, applying content analysis on two Nigerian daily newspapers cover page stories for the period of two month to assess level of press freedom in Nigeria. The article gives importance of freedom of press to the development of democracy and abuse of press freedom in Nigeria, "a country with oldest, richest in traditions, pluralism and development in history of African journalism" (Pate, 2002). The three Britain former political colonies which include: Ghana, Nigeria, and Kenya were among the best developed press based on long history in African continent (Eribo \& Ebot 1997). Historically, Nigerian press had kept changing direction from nationalism and a democratic culture to instrument of propaganda for the regional, ethnic and religious bigotry (Oyeleye 2004).

The press remains popular pillar of democracy. In his speech on 2008 world press freedom, former American President George Bush emphasized importance of the role of the press and mentioned that press freedom was enshrined in the United States constitution (Bush 2008). This is similar to many countries in world which Nigeria is among. The provision of Press Freedom is enshrined in 1999 Nigerian constitution of sections 39(1) which states, "Every person shall be entitled to freedom of expression, including freedom to hold opinions and to receive and impart ideas and information without interference". Section 39(2) guarantees that, "...every person shall be entitled to own, establish and operate any medium for the dissemination of information, ideas and opinions." Section 22 gives the press the right to hold the government accountable to its citizens, it guarantees, "The press, radio, television and other agencies of the mass media shall at all times be free to uphold the fundamental objectives contained in this chapter and uphold the responsibility and accountability of the Government to the people." Section 16 gives the press the right to hold governors accountable for good discharging their duties, and to "control the national economy in such a manner as to secure the maximum welfare, freedom happiness of every citizen on the basis of social justice and equality of status and opportunity". 
Sani, A.A. / Journal of Yaşar University 2014 9(35) 6099-6108

The notion is that, independence of press from the state is an essential factor in the democratic environment in mediating between private domain and political elite in public sphere. Democracy has globally opened up spaces for sustenance of press organizations. In Africa, putting an end to dictatorial military governments and replaced by civilian administrations, media industry has witnessed crucial shifts and remarkable expansion of media pluralism (Karikari 2004). However, Jacob (2002) argues that, democracy is largely leans on effective communication system channeled through mass media. It is unfortunate, however, the press which ideally tasked to promote democratic principles and to help individual form their opinions in a rational way resorts to protect elite interest at the disadvantage of larger society. The existing article divided into three sections. After the brief introduction, second section intends to justify rationale behind this study, then following the brief literature review, and an overview of press situation in Nigeria. After stating the situation, the third section includes the findings of the content analysis and the last section intends to sum up the research findings and make a conclusion.

\section{The Problem}

In spite of the abundance of different viewpoints emanating from mass media outlets, Nigerian society is not yet free and open. The lack of complete freedom especially in broadcast due to censorship, multiple power centers and rapid changes in political institutions jeopardizes free press in Nigeria (Agbaje 1992). Military coups and transitions to civilian administration affected the press freedom as every government in power has its unique relations with the press. Sustainability of democracy could be myth in the absence of complete press freedom. Democracy is not only about rights, it is also about participation and, interest representation.

The press freedom in the present dispensation in Nigeria is the primary concern of this article. Citizens in nominal democratic societies lacking complete free press may likely become victims to violence. In many countries, police brutality is mated out on members of the press including journalists and editors who observed professionalism and not succumb government to influence public opinion. According to Bush (2008), Nigeria, China, Cuba and Eritrea were among the countries with high rate of arrested and incarcerated journalists in 2007. In this light, this article analyses how Nigerian press does cover the federal government of Nigeria. The study uses two national daily newspapers and focuses on cover page lead stories to enable the research assess whether the news reports on Vanguard and Daily Trust front-page seem favorable or critical to the government.

\section{Literature Review}

There has always been an interrelationship between mass media and conduct of politics. Both in totalitarian and authoritarian regimes, political elite use their control of mass media to achieve popular support (McQuail 2005). Accordingly, McQuail (2005) maintained that, in liberal democracies, the press freely operates within spectrum of law, but conflicts still occur in relations with government and with the powerful institutions. Few countries have good record for free press and many countries are struggled to attain such level which Nigeria is inclusive. In global terms, Benin Republic topped a list of African countries on the 2005 global press freedom index (Word Bank 2006). Kohnert (2006) observes that, pluralism of private radio stations which regarded as agents of cultural change facilitate the promotion of democracy at local level through public discourse and political communication.

Tremendous contributions of community radio stations cannot over be emphasized. In the Democratic Republic of Congo, the establishment of such radio stations played vital role in transition journey to democracy by dissemination of necessary information citizens need to know, including relatively isolated citizens living in conflict areas. Tetty (2008) reveals that over ninety private radio stations were established in Madagascar since the late 1990. Private media contributed to the sustenance of democracy and promote the circulation of news and opinion within the politically interested public during the election period.

McQuail (2005) outlines significant roles of mass media in democratic campaign which include, periodic campaign for elections, continuous flow of news reflects positively or negatively on governments and other political actors, and political advertising various studies have proven effects of vibrant media milieus on public with their political engagement. "The most studied communication is that of electioneering with research going back at least until 1940, when Lazersfeld et al (1944) made a detailed inquiry into the presidential election of that year. Since then thousands of democratic elections have been an object of research with some consistency in broad findings about effects" (McQuail 2005, 524).

Kuenzi \& Lambright (2007) suggest that, there is a strong correlation between media exposure and voter turnout in African countries that have two consecutive multiparty general elections early 1990s. Therefore, access to information affects discourses and popular political participation, and facilitates political communication as well. 
Sani, A.A. / Journal of Yaşar University 2014 9(35) 6099-6108

The mass media as a source of information is expected to be reliable, but in some countries, dictatorship adulterated the information emanated from media to control public opinion and ensure conformity.

In Africa, it is obvious that many countries lack civil liberties as a result of authoritarian regimes. Nigeria, the most populous black nation in the world inherited elitist constitution from colonial powers imposed on the citizens whom subsequently passed on by military to civilian administrations that yet does not reflect need of the diverse nations in the country (Nwabueze 1997). The next section is defines situation in Nigerian media and specifically the press.

\section{Overview Of Nigerian Press}

Nigeria is a former political colony of Britain that got independence in 1960. The Federal Republic of Nigeria is a federal constitutional republic comprising 36 states and Federal Capital Territory, Abuja. The country is located in the West Africa and shares land boarders with the Republic of Benin in the west, Chad and Cameroun in the east, and Niger in the north. Its coast in the south lies on the Gulf of Guinea on the Atlantic Ocean. Nigeria is roughly divided in half between Christian who mostly live in South and Muslims concentrated mostly in the North. A minority of the population practice traditional religions. Nigeria is the most populous African country and seventh most populous country in the world. According to CIA, The World Fact Record, Nigerian population estimate of July, 2013 accounts roughly 175 million.

The press organizations started in Nigeria with Iwe Iroyin newspaper in 1859 by Henry Townsend in Abekuta (Abati 1998). Robbert Campbell established the second newspaper called The Anglo-African in 1863 primarily to promote the interactivity between Britain and Africa (Dare and Uyo 1996). The Lagos Times and Gold Coast Colony Advertiser were established in 1880 by Rchard Beale Blaize (Abati 1998). The success of Lagos Times became the precursor to the proliferation of print media in the country.However, about nine decades after the establishment of the press, broadcast media started up in the 1936 with the establishment of Radio Distribution Service in Lagos disseminated British Broadcasting Corporation programs. In the 1950s, former Western Region established Western Nigeria Television, and then followed by rapid emergence of radio and television stations across the country. In 1961, Nigerian Broadcasting Corporation was mandated by law to regulate the broadcast media in the country. There is a combination of both public (federal and states government) and private media ownership. There are 48 television stations owned by the Federal Government which operate by Nigerian Television Authority (NTA), state governments have 37 stations, and 15 are privately owned. The Federal Radio Corporation of Nigeria has 43 radio stations, 40 owned by states, 24 campus radio, and the Voice of Nigeria (VON) and 24 private (NBC website 2013). In the case of print media, there are over 90 titles of newspaper publications and over 40 hundred magazines titles. The accurate figure cannot be easy to get because of political and economic reasons that publications are closing down and new ones are coming up rapidly.

In Nigeria, after independence in October 1960, Decrees ${ }^{1}$ and regulations were promulgated to control and repress the press. Newspaper (Amendment) Act of 1964 and the Sedition Law of 1964 were among the several decrees the government. During the Nigerian civil war in 1967, the military promulgated war time Newspaper Decree 17 and Decree 24. Decree 24 gave absolute to the inspector-general of police and the army chief to detain without trail for an indefinite period anyone considered to a security risk (Sabowade 1985). Among first generation of Nigerian press who experienced censorship during the military colonialism include: Peter Enahoro, Tom Borha, Wilson Uwaifo, Michael Asaju, Sam Amuka, Neville Ukoli, Lateef Jakande, Sam Eguavven, Dan Agbase, Ray Ekpu, Lade Bonuola and Iro O morodion (Eribo \& Jong-Ebot 1997). Several cases of arrests have been documented where a number of journalists have been arrested, intimidated and jailed for news reports the government considered embarrassing. For example, Tampson Thompson, Ndika Irabor of the Guardian newspaper, Femi Akande of Fame Magazine, Nosa Igeibor, Kola Ilori, Onome Osifo-Wiskey and Ayodele Akinkouotu of Tell Magazine were incarcerated while discharging their journalistic duties. It was also recorded that, police attacked and arrested members of the press of The Observer, The News and Daily Independent from 1999 - 2003 of Obasanjo civilian administration (Onadipe 2002). This cruelty of police was as a result of accusation on the press of being critical and unfair reports and editorials on the Nigerian Government. As such, the press function of watchdog and surveillance

\footnotetext{
${ }^{1}$ A Decree is a rule of law issued by dictatorial military government for policy legitimization. Even after transition to democratic government, such Decrees are recognize as Laws since they were passed by the Federal Military council after deliberation presided over by the military head of state.
} 
were curtailed and repressed with marginalization of Nigerian populace. The Nigerian situation is among the bad cases of press freedom (Akinwale 2010).

\section{Methodology}

The research method in this study is content analysis using random sampling of two Nigerian daily newspapers cover page news, The Vanguard and Daily Trust that published in Lagos and Abuja respectively. What inferred the choice of these newspapers was the Vanguard is the most widely circulated newspaper in Nigeria, published in the southern part; whereas Daily Trust ranked ninth, with largest readership from north. The selection was based on readership and representativeness of place of publication (North and South).

Due to the paucity of time, a period of two month is considered for analysis, from November to December, 2013. Simple random sampling will be used, where each unit has an equal chance of being selected. The table of random sample dates will be drawn from $1^{\text {st }}$ November to $31^{\text {st }}$ December starting from $3^{\text {rd }}$ November which is selected at random, and then used interval of three units. Totality, eighteen cover pages news stories were analyzed.

The limitation of the study is, it ignores broadcast media and magazine, and focuses on newspapers only. It happened due to the insufficient time of the researcher to monitor broadcast contents. Magazine is published weekly, fortnightly and monthly in some cases whereas sample may be inadequate for the research.

\section{Discussion}

A sample of 227 items of news stories were recorded on the two selected newspapers over the period of study. Individually, there was significant difference between the coverage of newspapers in terms of widespread criticism on the government. Perhaps, this could be explained by the geographical location, religion and ethnicity which divided the Nigerian press. It is argued that southern press has been exaggerated reportage on negative happening in the North, while northern press tries to give exact picture but exaggerates in positive side. Along this line, southern press severely criticized Nigerian government under the leadership of northerners such the governments of General Sani Abacha, General Babangida among others due to sectional, ethnical and religious interests. The Northern press was so critical on government of General Obasanjo and the present administration of President Jonathan, both were Christians and hailed from south, but received sympathy from southern press. In this light, it does not mean both southern and northern press never report negatives on the government on power that comes from their section, religion and ethnicity, but rather enjoy some level of sympathy.

The cover page news stories were categorized into three, positive, negative and neutral. Positive refers to a category of news stories that depict good image on the government. Negative classified as news coverage that is against government and cannot be published in government owned newspapers. Neutral is the last category that belongs to neither positive nor negative. The table below contains details.

Table 1: Press Freedom in the Selected Newspapers

\begin{tabular}{|l|l|l|l|l|}
\hline Newspaper & Positive & Negative & Neutral & Total \\
\hline Vanguard & 39 & 27 & 51 & 117 \\
\hline Daily Trust & 15 & 39 & 56 & 110 \\
\hline & $54(23.7 \%)$ & $66(29 \%)$ & $107(47 \%)$ & 227 \\
\hline
\end{tabular}

The free press in Nigerian newspaper which reflected in the Table 1 shows significant gap between positive and negative coverage i.e. $23.7 \%$ for positive and $29 \%$ for negative, with $47 \%$ as neutral coverage. From this result, it reveals that, the press in Nigeria is considerably free since it repeatedly reports issues that are critical to the Federal Government of Nigeria by giving such stories prominence on cover page of the newspapers. The study supports the United Nations who rates Nigerian press as one of the world's freest. According to United Nations' Resident Coordinator, Mr. Doauda Taure, "The press in Nigeria is regarded as one of the freest in the world in spite of impunity and attacks” (Punch Newspapers May 4 2013).

Table 2: Topic/ theme of the newspaper text

\begin{tabular}{|l|l|l|l|l|l}
\hline Politics & Education & Business & Crime & Religion & Total
\end{tabular}




\begin{tabular}{|l|l|l|l|l|l|l|}
\hline Vanguard & 70 & 16 & 14 & 10 & 7 & 117 \\
\hline Daily Trust & 72 & 14 & 11 & 8 & 5 & 110 \\
\hline & $142(62.5 \%)$ & $30(13.2 \%)$ & $25(11 \%)$ & $18(7.9)$ & $12(5.2 \%)$ & 227 \\
\hline
\end{tabular}

The 227 sample that comprised news items of politics, education, business, crime and religion were found in both Vanguard and Daily Trust newspapers. It reveals that, political news was largely covered by the both newspapers which enjoyed $62.5 \%$, education $13.2 \%$, business $11 \%$, crime $7.9 \%$ and religion $5.2 \%$. Therefore, Nigerian press has keen interest in the country's polity as $62.8 \%$ news coverage was devoted to this theme.

Individually, the Vanguard reported more positive news with 39 as against 27 negative items. On the contrary, Daily Trust covered more in the negative direction with 39 as against 15 positive news items. Both the newspapers reported more neutral news stories.

\section{Conclusion}

The contribution of press to the consolidation of democracy cannot be over emphasized. Nigerian citizens have been enjoying wider access to variety of information for both overview and in-depth on public and political life. The literature reviewed particularly on Nigerian case suggested the excessive repression of press and suppression of press freedom. On the contrary, scrutiny on the finding of this study reveals that Nigerian press operates in a considerable free environment. The contradiction may be due to the dearth of new studies, and the reviewed literatures were relatively old. After the transition from military to democratic government, Nigeria witnesses pluralism of emergence of new mass media outlets. Press organizations in the country usually cover public outcry over the lack of government transparency and insecurity and widespread of corruption in the political system.

This study, however, reveals that, about $23.7 \%$ of news items were positive, $29 \%$ negatives, whereas $47 \%$ were categorized as neutral. In this light, it shows a significant freedom of press in Nigeria to the extent that newspapers were carried criticism about public policies and government officials that consider as highly critical of the government on the front-page. It further reveals Nigerian press gave more importance to issues on politics with $62.5 \%$ than education $13.2 \%$, business $11 \%$, crime 7.9 and religion which carried $5.2 \%$. The study was limited to a short period of study and an examination of few sample which probably more sample would have reveal more valuable information. The focus of the study was on print media, it would be valuable to study other media as well. Despite the limitations of this study, its findings are valid and yield an insight for subsequent studies.

However, the environment of Nigerian journalism suggests embarking on investigative reporting that digs beyond surface to strengthen existing democratic institutions. The line of ethnicity, religion and sectionalism which have been threatening professional ethics and practice in Nigerian press should be blurred in the interest of sustainable unity, the citizens and popular democracy and also to retain a repute of the press.

\section{REFERENCES}

Abati, Reuben 1998. Press Freedom in Nigeria. Lagos: Bolaji and Associates.

Agbaje, Adigun Ajao B. 1992. The Nigerian Press, Hegemony, and the Social Construction of Legitimacy: 19601983. Lewiston, NY: The Edwin Mellon Press.

Aiyede, Remi. 2000. The Dynamics of Civil Society and the Democratization Process In Nigeria. Paper Presented during the Fellowship at the Transregional Center for Democratic Studies (TCDS), New School University, New York, September-December 2000.

Ayofe, Akinwale A. 2010. Repression of Press Freedom in Nigerian Democratic Dispensations. African Development, V 35; 47-70.

Bruns, Axel. 2008. Life Beyond the Public Sphere: Towards a Networked Model of

Political Deliberation. Information Polity, V 13; 65-79.

Bush, George W. 2008. Statement on World Press Freedom Day. Weekly Compilation of Presidential Documents, 5 May, V 44; 636-637.

Dare, Olatunji \& Uyo, Adidi. 1996. Journalism in Nigeria: Issues and Perspectives. Lagos: Nigerian Union of Journalist.

Duyile, Dayo. 1979. Media and Mass Communication in Nigeria. Ibadan: University Press.

Eribo, Festus. \& Jong-Ebot, William. 1997. Press Freedom and Communication in Africa. Asmara: Asmara: Africa World Press.

Karikari, Kwame. 2004. Press Freedom in Africa. New Economy, V 11; 67-80.

Kohnert, Dirk. 2006. Afrikanische Migranten Vor den'Festung Europa. Hamburg: Giga Focus Afrika. 
Kuenzi, Michelle \& Lambright, Gina. 2007. Voters Turnout in Africa's Multiparty Regimes. Comparative Political Studies, V 40; 665-690.

Kukah, Mattew H. 1993. Religion, Politics and Power in Northern Nigeria. Ibadan: Spectrum.

McQuail, Denis. 2005. Mass Communication Theory. London: Sage.

Norris, Pippa. 2006. Did the Media Matter? Agenda-Setting, Persuasion and Mobilization Effects in the 2005 British General Election. British Politics, V 1; 195-221.

Nwabueze, Ben. O. 1997. Decolonizing and Democratizing the Constitution in Africa. Paper presented at The Annual Lecture in Law and Public Policy, University of Ilorin - Nigeria.

Onadipe, Abiodun. 2002. Nigeria and Democracy: Third Time Lucky? Ibadan: Contemporary

Review Company Ltd.

Oyeleye, Ayo. 2004. The Mediation of Politicians and the Political Process in Nigeria. Journal of Human Development, V 4; 29-46.

Pate, Umaru A. 2002. The Press and the Babangida Regime IBB: A Heritage of Reform. Abuja: Heritage Press Limited.

Pate, Umaru. A. 2011. The Press, social responsibility and the coverage of human rights in Nigeria during the Abacha regime. Lagos: Malthouse Press Limited.

Spinks, Todd. B, Sahliyeh, Emile. \& Calfano, Brain. 2008. The Status of Democracy and Human Rights in the Middle East: Does Regime Type Make a Difference? Democratization, V 15; 321-341.

Tettey, Wisdom J. 2008. Media Pluralism, Democratic Discourses and Political Accountability in Africa. Paper presented at the Harvard World Bank Workshop, Harvard Kennedy School. 20-31 May 2008.

World Bank, (2006). World Development Report 2006: Equity and Development. Washington, D.C.: Oxford University Press.

1999 Constitution of the Federal Republic of Nigeria. 